\title{
Indications of climate change in coastal areas: what may fish otoliths tell us?
}

\author{
Rüdiger Berghahn* \\ Umweltbundesamt, Versuchsfeld Marienfelde, Schichauweg 58, 12307 Berlin, Germany
}

\begin{abstract}
The relative occurrence of hyaline zones in the otoliths of the 0-group of certain flatfish species may serve as an indicator for changes in UV-B radiation in the course of climate change. The importance of factors other than UV-B, which are also related to climate change, is discussed.
\end{abstract}

KEY WORDS: Climate change - Flatfish · Tidal flats · Environmental stress · UV-B radiation · Hydrogen peroxide $\cdot$ Otoliths $\cdot$ Biological tags

\section{INTRODUCTION}

In the light of increasing UV-B radiation in the course of global climate change (Breitbart et al. 1998), there is a demand for indicators to enable monitoring of the biological effects of UV-B radiation in potentially affected environments. In general, aquatic animals are more endangered by increased UV-B radiation if they live at or close to the water surface or in tidal areas (Forster \& Kestler 1998). Along the North Sea coast, the transition to a bottom-dwelling mode of life in the 3 flatfish species plaice Pleuronectes platessa, flounder Platichthys flesus and sole Solea solea and a number of other fish species occurs in the extreme shallows. In areas with extensive tidal flats such as the Wadden Sea, a major part of the early postlarvae are found in tidal pools at water depths of a few millimetres to centimetres (Berghahn 1983, Van der Veer 1986). Here they may be subjected to high doses of solar radiation. This may cause the deposition of a pronounced hyaline zone in their otoliths if the tidal flats are exposed around noon on cloudless and windless days (Berghahn 1989, Berghahn et al. 1993, Fig. 1). Radiation stress is asssociated with temperature stress, since water temperature in the pools may reach lethal limits. In this case, mass escapes of newly metamorphosed flatfish postlarvae towards the subtidal can be

*E-mail: ruediger.berghahn@uba.de observed during low tide in the drainage gulleys on the tidal flats (Berghahn 1983). In the course of these exoduses 14 to $27 \%$ of the settlers may be killed (Berghahn et al. 1993). The survivors will no longer be found in the tidal pools, but will start to exhibit tidally phased feeding migrations onto the submerged tidal flats. They can later be identified since they have this first hyaline zone surrounding the nucleus of their otoliths, whereas the first hyaline zone is lacking in settlers that have not been exposed to high doses of UV-B radiation during the pool-dwelling mode of life.

Year-class strength in marine fishes is determined by mortality occurring during the egg and larval stage (Leggett \& Deblois 1994). In plaice, actual and predicted UV-B levels seem to be of minor importance for mortality at this stage of life history (Dethlefsen et al. 2001, Steeger et al. 2001). However, the transition to a bottom-dwelling mode of life has been suspected to be a second critical phase associated with increased mortality (see Beverton \& Iles 1992). An increase in the percentage of specimens with an early hyaline zone in their otoliths would point at an increased role of radiation effects, providing further explanation for decreases in year-class strength, which is routinely assessed for Total Allowable Catch (TAC) management in North Sea flatfish fisheries (Daan 1997). This paper examines the possibility of using the hyaline zones as indicators for monitoring the effects of climate change. 

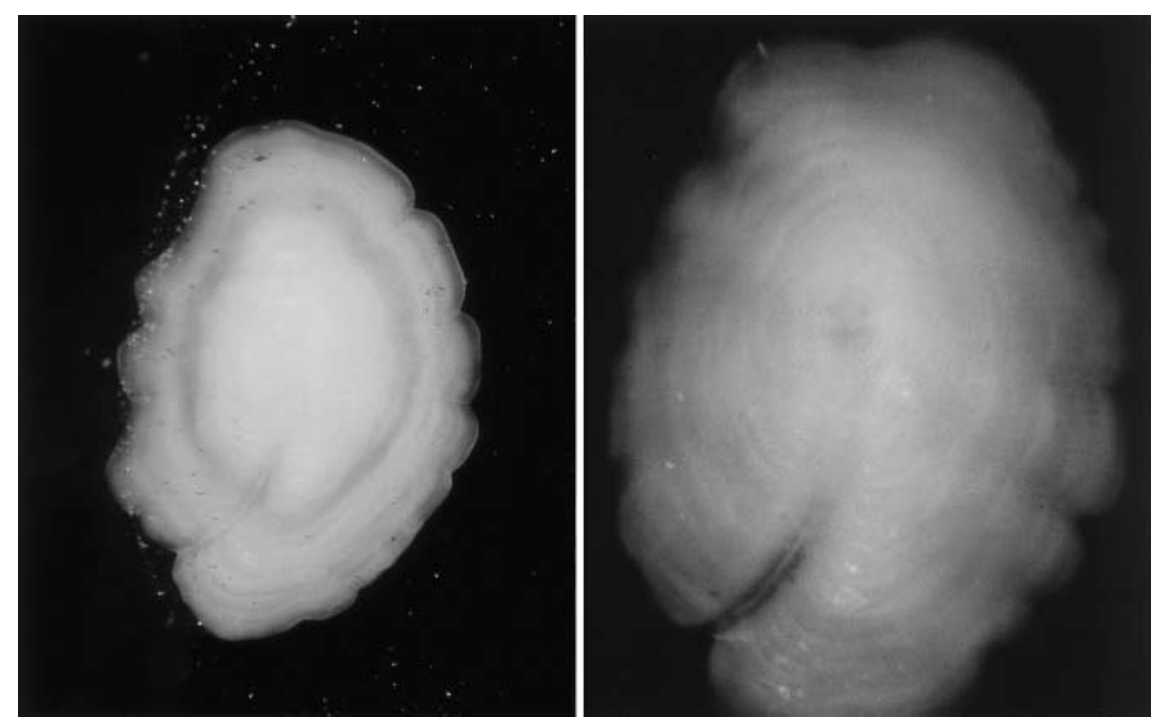

Fig. 1. Otoliths of 0-group plaice with and without hyaline zone (from Wadden Sea proper and outer sand bars at the border of the Wadden Sea to the open North Sea respectively)

\section{VARIABILITY OF THE INDICATOR IN SPACE AND TIME AND CONSEQUENCES FOR SAMPLING STRATEGIES}

The percentage of specimens having these biological tags differs according to hydromorphology and the prevailing weather conditions during and after settling (Berghahn 2000, Figs 2 \& 3). Consequently, sampling for routine monitoring should be carried out in clearly defined areas which meet the following requirements: (1) A tidal range of $\sim 2.5 \mathrm{~m}$, which will bring the specimens to the residual waters on more elevated tidal flat areas. Here they may be exposed to solar radiation for a longer time period. (2) Mixed sediments, which will prevent the tidal pools from being completely drained during low tide, since residual water is essential for the survival of plaice and flounder postlarvae. (3) Little exposure to wave action. (4) High exchange of water.

Shallow bays with no wave exposure and low water exchange should not be the main sampling area. For example, in long bays in the Wadden Sea resulting from dam and dike building as well as in the manmade Wadden Sea lagoon between the islands Sylt and Rømø, the water body close to the shore is hardly mixed, particularly if wind force is low. In these areas up to 4 hyaline zones can be found in the otoliths of 0 -group plaice (Fig. 4). This indicates that the hyaline zones do not result from a direct UV-B effect, but a UVB mediated oxidative stress (Berghahn 2000) which is linked to the high DOC content of the water close to the shore (Abele-Oeschger et al. 1997). If this is so, hyaline zones that are deposited prior to the first annu- lus may well have been deposited in tidally migrating flatfish subassemblage, inhabiting the edges of tidal channels during low tide in areas with low water exchange (Berghahn 2000). For that reason, samples from nearshore areas with low water exchange would have to undergo an additional, labor intensive validation employing microstructure analysis (Berghahn \& Karakiri 1990) in order to be sure that the first hyaline zone in 0-group plaice otoliths result from mass escape situations. It is only the hyaline zone resulting from these exoduses that are known to be associated with mortality. In contrast, the effects on population dynamics indicated by multiple ring formation are unknown. Nevertheless, it may be worthwhile to monitor multiple ring formation in additional samples, for example in the lagoon between the islands Sylt and Rømø.

The distribution pattern changes in the course of the season due to migration (Fig. 5). The optimal time for sampling would be 2 to $4 \mathrm{wk}$ after settlement of the 'young of the year' of the corresponding species has been completed. This time interval is necessary in order to allow a potential hyaline zone to separate from the margin (growth zone) of the otolith, which is generally hyaline. In the Wadden Sea, plaice would be the best species to work with, since they are most abundant and tidally migrating subassemblages are temporarily isolated in nearshore areas, which are clearly delimited (Kuipers 1977, Zijlstra et al. 1982, Berghahn 1986, Berghahn et al. 1995), for example by high watersheds and tidal channels deeper than $5 \mathrm{~m}$ below mean low water level. In the Wadden Sea, 0-group flounder is most abundant on tidal flats close to fresh- 

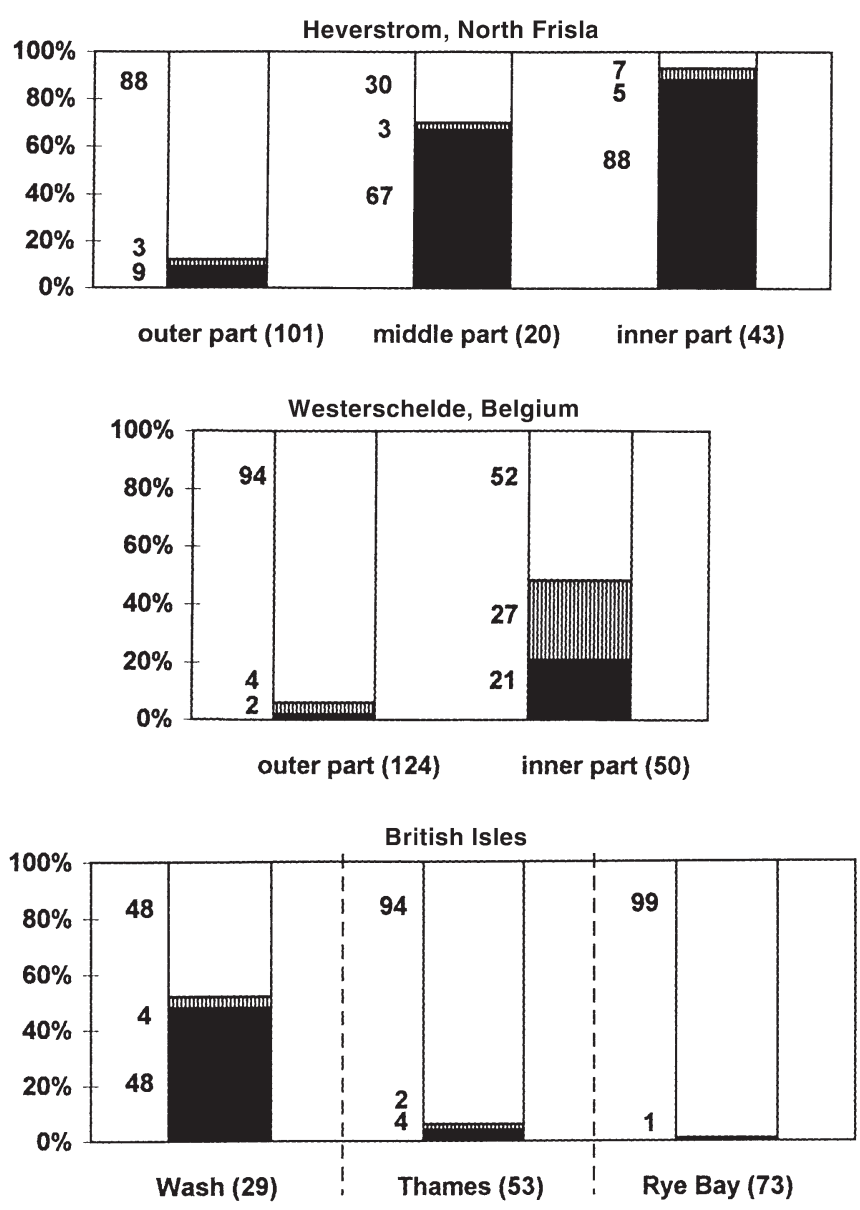

Fig. 2. Percentage of 0-group plaice with and without hyaline zones in otoliths at various sites along the coast of the North Sea (see Fig. 3). Number of specimens in parentheses. Black $=$ hyaline zones distinct, striped $=$ hyaline zones weak, white $=$ no early hyaline zone (from Berghahn 2000)

water inlets (Berghahn 1984, Jager 1999). However, immigration towards freshwater may be considerable after settlement (Berghahn 1984, Kerstan 1991, Bos 1999). In 0-group sole that have settled on the tidal flats in the Wadden Sea, migration towards the deep is much faster compared to plaice (Berghahn 1984). In contrast to plaice and flounder, early postlarvae of sole that have settled on the submerged tidal flats do not seem to depend on residual waters, but may also survive buried on tidal mud flats (Berghahn 1984). They can also tolerate higher water temperatures than plaice and flounder (Berghahn 1984). However, this advantage is neutralized by the fact that at the German North Sea coast, settlement of sole occurs $\sim 1$ mo later in the year than in plaice and flounder (Berghahn 1987), when water temperature in tidal pools may reach highest values. Finally, sole are more difficult to sample since gear efficiency is much lower than for plaice due to greater mesh selection, escape underneath, etc. (Berghahn 1984).

\section{ACCURACY OF THE SIGNAL FOR INDICATING CLIMATE CHANGE}

Theoretically, the percentage of 0-group specimens from a selected site that have these tags in their otoliths could serve as a measure for increased plaice mortality right after settling, due to increased solar radiation in the course of climate change. The Wadden Sea area 'Hörnumtief', to the south of Sylt Island, which has recently been selected as a reference area for monitoring, would be promising as a sampling area. However, the signal is also driven by other factors that are likely to undergo changes in the course of global climate change:

- Changes in dissolved organic carbon (DOC; yellow substances) in coastal waters may dampen UV-B penetration of the water column (Berghahn et al. 1993). On the other hand, UV-B mediated oxidative stress (hydrogen peroxide), which seems to play a major role in the formation of the hyaline zones in otoliths (Berghahn 2000), may be increased (AbeleOeschger et al. 1997) and thereby compensate for a reduction in zone deposition.

- Wind stress in the Wadden Sea is expected to change with climate (Hofstede 1993) and may reduce UV-B penetration in tidal pools due to increased reflection at the water surface and higher water turbidity (Berghahn et al. 1993). Nevertheless, calm periods will continue to occur.

- Sea level rise and its consequences for the hydrology and the morphology of the Wadden Sea are expected not to endanger populations, since there will be enough other areas for the species to move over to (Wolff et al. 1993). However, changes in the hydrography of the Wadden Sea (Reise 1996, Backhaus et al. 1998, Reise et al. 1998) and, in particular, tidal amplitude may bring settling flatfish larvae to more elevated tidal flat areas. Here, as pool-dwellers, they may be exposed to solar radiation for longer diurnal periods, resulting in greater likelihoods of direct and indirect solar stress. However, in the Wadden Sea a tidal amplitude of $2.5 \mathrm{~m}$ is already in the upper range. In these areas, hyaline ring formation is already pronounced and mainly dependent on weather conditions.

- Changes in water temperature and salinity may alter settlement and migration patterns and thereby complicate the choices made with regard to sampling strategy, in terms of temporal and spatial variability (Van der Veer 1986). These changes, however, can be considered to operate more slowly than the changes in UV-B radiation. 


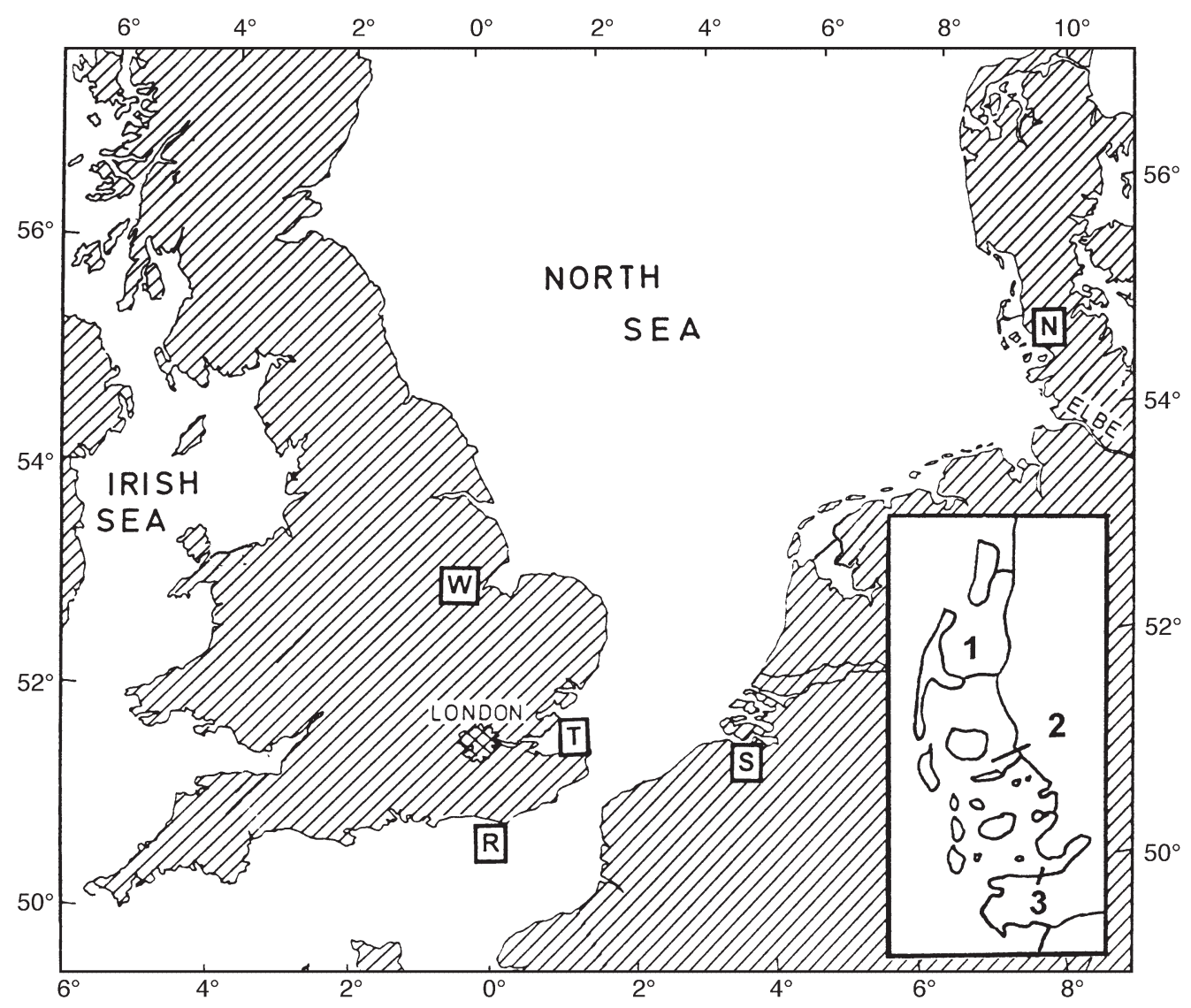

Fig. 3. Sampling sites with $(\mathrm{N}=$ North Frisian Wadden Sea, $\mathrm{S}=$ Westerschelde estuary, $\mathrm{W}=$ Wash) and without extended tidal flats ( $\mathrm{R}=$ Rye Bay, $\mathrm{T}$ = Thames estuary). Insert: 1 = Rømø-Sylt lagoon, 2 = Norderaue, 3 = Heverstrom (after Berghahn 2000)

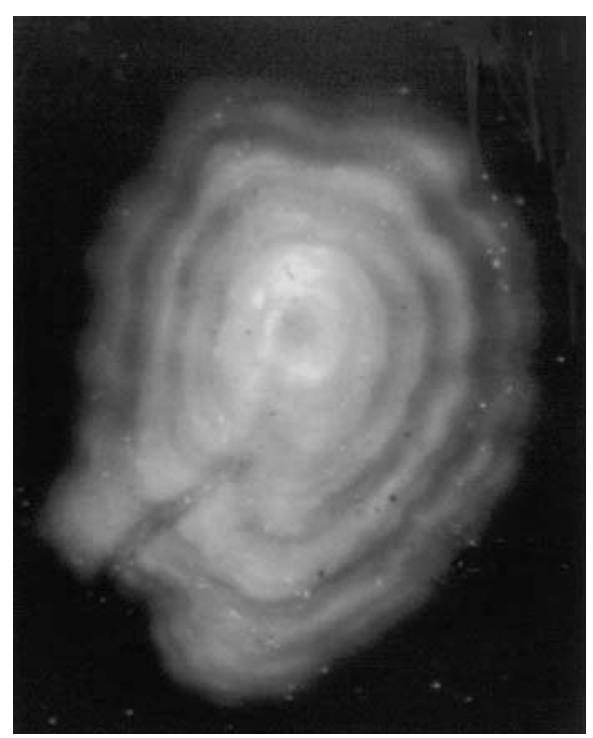

Fig. 4. Multiple hyaline zone formation in otoliths of 0-group plaice from the man-made lagoon between the islands Rømø (Denmark) und Sylt (Germany) (Fig. 3, from Berghahn 2000)

\section{CONCLUSION}

It may be worthwhile to include otolith sampling in local climate monitoring, since the reference area 'Hörnumtief' will be sampled in the monitoring framework for the Wadden Sea anyway, the effort required is moderate, and the factors mentioned above are also monitored. Whole fish samples can be preserved in ethanol for long-term storage (Butler 1992). In formalin-preserved samples, otolith dissolution is a problem. For examination, the otoliths should be removed, cleaned and rinsed in 96\% ethanol and embedded on a dark background in epoxy resin, which may serve as both a clearing medium and an ideal medium for long-term storage. The second otolith could be stored in alcohol in order to have the option for additional microstructure analysis. Comparisons with samples from earlier decades are possible. In older specimens, slight grinding of the otoliths may be necessary in order to make the hyaline ring close to the nucleus visible again (Maier 1908). 


\section{September 1988}

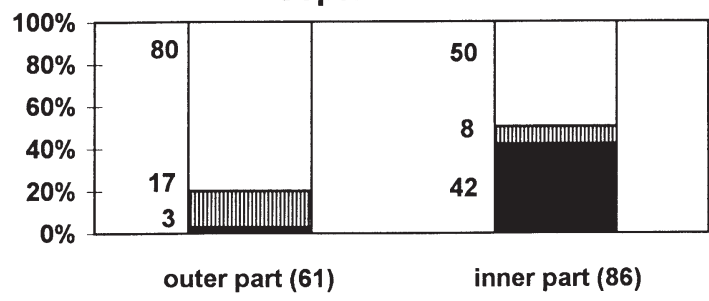

December 1988

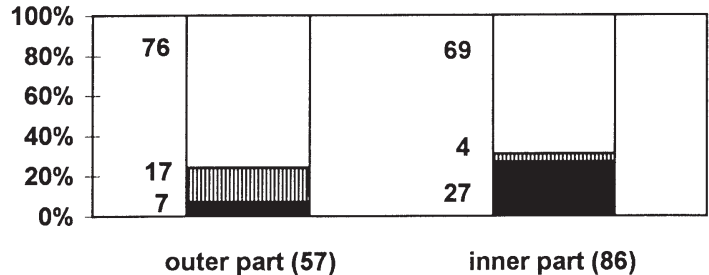

outer part (57)

inner part (86)

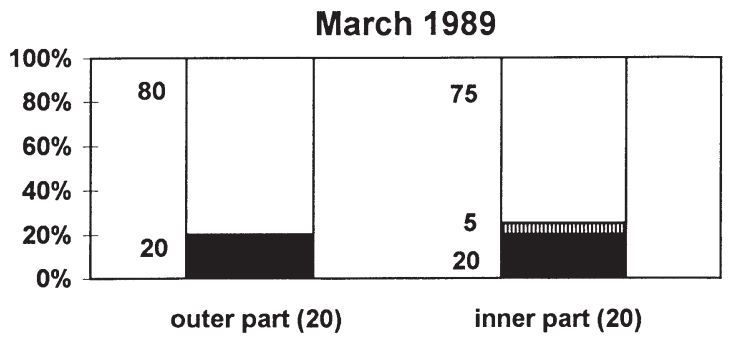

Fig. 5. Changes in the percentage of 0-group plaice with early hyaline zones in the otoliths in the Norderaue (North Frisian Wadden Sea, Fig. 3). Number of specimens in parentheses. For legend see Fig. 2 (from Berghahn 2000)

\section{LITERATURE CITED}

Abele-Oeschger D, Tüg H, Röttgers R (1997) Dynamics of UV-driven peroxide formation on an intertidal sandflat. Limnol Oceanogr 42(6):1406-1415

Backhaus J, Hartke D, Hübner U, Lohse H, Müller A (1998) Hydrographie und Klima im Lister Tidenbecken. In: Reise K, Gätje C (eds) Ökosystem Wattenmeer: Austausch-, Transport- und Stoffumwandlungsprozesse. Springer, Berlin, p 39-54

Berghahn R (1983) Untersuchungen an Plattfischen und Nordseegarnelen (Crangon crangon) im Eulitoral des Wattenmeeres nach dem Übergang zum Bodenleben. Helgol Meeresunters 36:163-181

Berghahn R (1984) Zeitliche und räumliche Koexistenz ausgewählter Fisch- und Krebsarten im Wattenmeer unter Berücksichtigung von Räuber-Beute-Beziehungen und Nahrungskonkurrenz. PhD thesis, Universität Hamburg

Berghahn R (1987) The Wadden Sea as a nursery for fish and crustacean species. In: Tougaard S, Asbirk S (eds) Proceedings of the 5th International Wadden Sea Symposium, Esbjerg, Danmark. National Forest and Nature Agency and Museum of Fishery and Shipping, Esbjerg, p 69-85

Berghahn R (1989) Environmentally induced biological tags in otoliths of 0-group plaice (Pleuronectes platessa L.) confirmed by daily increment readings. Rapp P-V Rèun Cons Int Explor Mer 191:464
Berghahn R (2000) Response to extreme conditions in coastal areas: biological tags in flatfish otoliths. Mar Ecol Prog Ser 192:277-285

Berghahn R, Bullock A, Karakiri M (1993) Effects of solar radiation on the population dynamics of juvenile flatfish in the shallows of the Wadden Sea. J Fish Biol 42:329-345

Berghahn R, Lüdemann K, Ruth M (1995) Differences in growth of newly settled 0-group plaice (Pleuronectes platessa L.) in the intertidal of neighbouring Wadden Sea areas. Neth J Sea Res 34(1-3):131-138

Beverton RJH, Iles TC (1992) Mortality rates of 0-group plaice (Pleuronectes platessa L.), dab (Limanda limanda L.) and turbot (Scophthalmus maximus L.) in European waters. II. Comparison of mortality rates and construction of life table for 0-group plaice. Neth J Sea Res 29(1-3):49-59

Bos A (1999) Aspects of the life history of the European flounder (Pleuronectes flesus L. 1758) in the tidal river Elbe. $\mathrm{PhD}$ thesis, Universität Hamburg

Breitbart EW, Greinert R, Volkmer B (1998) Gefährdung durch verstärkte UV-Strahlung. In: Lozán JL, Graßl H, Hupfer P (eds) Warnsignal Klima-wissenschaftliche Fakten. Wissenschaftliche Auswertungen, Hamburg, p 341-347

Butler JL (1992) Collection and preservation of material for otolith analysis. In: Stevenson DK, Campana SE (eds) Otolith microstructure examination and analysis. Can Spec Publ Fish Aquat Sci 117

Daan N (1997) TAC management in North Sea flatfish fisheries. J Sea Res 37(3-4):321-341

Dethlefsen V, von Westernhagen $H$, Tüg $H$, Hansen PD, Dizer $H$ (2001) Influence of solar ultraviolet-B on pelagic fish embryos: Osmolality, mortality and viable hatch. Helgol Mar Res 55:45-55

Forster RM, Kestler P (1998) Flora und Fauna unter einer verstärkten UV-B Strahlung. In: Lozán JL, Graßl H, Hupfer P (eds) Warnsignal Klima - wissenschaftliche Fakten. Wissenschaftliche Auswertungen, Hamburg, p 303-308

Hofstede J (1994) Meeresspiegelanstieg und Auswirkungen im Bereich des Wattenmeeres. In: Lozán JL, Rachor E, Reise K, von Westernhagen H, Lenz W (1994) Warnsignale aus dem Wattenmeer. Blackwell, Berlin, p 17-23

Jager Z (1999) Floundering - processes of tidal transport and accumulation of larval flounder (Platichthys flesus L.) in the Ems-Dollard nursery. PhD thesis, University of Amsterdam

Kerstan M (1991) The importance of rivers as nursery grounds for 0- and I-group flounder (Platichthys flesus L.) in comparison to the Wadden Sea. Neth J Sea Res 27(3/4): 353-366

Kuipers BR (1977) On the ecology of juvenile plaice on a tidal flat in the Wadden Sea. Neth J Sea Res 11(1):56-91

Leggett WC, Deblois E (1994) Recruitment in marine fishes: is it regulated by starvation and predation in the egg and larval stages? Neth J Sea Res 32(2):119-134

Maier HN (1908) Beiträge zur Altersbestimmung der Fische. I. Allgemeines. Die Altersbestimmung nach den Otolithen bei Scholle und Kabeljau. Wiss Meeresuntersuch (Abt Helgoland) NF 8(1):57-111

Reise K (1996) Wattökologische Folgen bei Änderungen von Klima und Küste. In: Schutzgemeinschaft Deutsche Nordseeküste (ed) Klimaänderung und Küste. Clausen \& Bosse, Leck, p 31-45

Reise K, Köster R, Müller A, Armonies W, Asmus H, Asmus R, Hickel W, Riethmüller R (1998) Austauschprozesse im Sylt-Rømø Wattenmeer: Zusammenschau und Ausblick. In: Reise K, Gätje C (eds) Ökosystem Wattenmeer: Austausch-, Transport- und Stoffumwandlungsprozesse. 
Springer, Berlin, p 39-54

Steeger HU, Freitag JF, Michl S, Wiemer M, Paul RJ (2001) Effects of UV-B radiation on embryonic, larval and juvenile stages of North Sea plaice (Pleuronectes platessa) under simulated ozone-hole conditions. Helgol Mar Res 55:56-66

Van der Veer HW (1986) Regulation of the population of 0group plaice (Pleuronectes platessa L.) in the Wadden Sea. PhD thesis, University of Groningen

Submitted: August 10, 1999; Accepted: March 22, 2001
Wolff WJ, Dijkema KS, Jens BJ (1993) Expected ecological effects of sea level rise. In: van Urk A, De Ronde JG (eds) State of the art report. SEACHANGE: sea level rise and the consequences for hydrology and water management. National Institute for Coastal and Marine Management, Den Haag

Zijlstra JJ, Dapper R, Witte JIj (1982) Settlement, growth and mortality of post-larval plaice (Pleuronectes platessa) in the western Wadden Sea. Neth J Sea Res 15:250-272

Proofs received from author(s): July 13, 2001 